Gémar y Espinar (2015) / Revista de Empresa Familiar, 5(1), 7-15.

www.revistadeempresafamiliar.uma.es

\title{
Communication about Corporate Social Responsibility practices and Return on Equity
}

\author{
Germán Gémar $^{\mathrm{a}^{*}} \cdot$ David Espinar ${ }^{\mathrm{b}}$ \\ ${ }^{a}$ Departamento de Economía y Administración de Empresas. Universidad de Málaga (Spain). \\ ${ }^{b}$ CSR Consultant.
}

\author{
A R T I C LE INFO \\ Article history: \\ Received 18-03-2015 \\ Accepted 15-04-2015 \\ Keywords: \\ CSR \\ Financial performance \\ ROE \\ Strategy \\ Ethics \\ JEL codes: \\ G10, G14, M14, M21
}

\begin{abstract}
A B S T R A C T
We have analysed the importance of companies' corporate social responsibility (CSR) and how the relationship between CSR and financial performance has been scientifically studied. It is clear that the literature offers contradictory results. This debate is particularly relevant in the hotel sector due to the intense relationship and dependency this industry has on its environmental setting.

This paper has shown a neutral relationship between the CSR and return on equity (ROE), which means introducing CSR measures stop short of having a negative effect on shareholders' profits. Therefore, based on the results of this study, we encourage the hotel sector to introduce CSR practices into its strategy, as CSR produces new competitive advantages that have neutral effects on financial performance. The conclusions were not different once we distinguished between family or non family firms.

One of the most common excuses business owners and executives use to justify having no CSR policies is that they cannot afford to spend money on these activities, as they will affect their companies' profitability. This study has demonstrated that CSR has a neutral relationship with ROE, and, consequently, other benefits (e.g. reputation and competitiveness) will arise from applying those practices, without weakening ROE.
\end{abstract}

\footnotetext{
* Corresponding author.

E-mailaddresses:ggemar@uma.es*,despinar@me.com
} 


\section{Introduction}

Maintaining or improving shareholders' profits or return on equity (ROE) is necessarily the strategic purpose of every company (Jarillo, 2002 and Gemar \& Jimenez, 2013). Nevertheless, this goal is not easily achievable. Some companies find globalisation is the best way to reach this goal, taking into account several variables, such as country risk and cultural distance (Kogut \& Singh, 1988; Pla \& León, 2004; Drogendijk \& Slagen, 2006; Kim \& Gray, 2009; Morschett at al. (2008); López-Duarte \& Vidal-Suarez, 2010 and Gemar, 2014). However, globalisation is not an easy process, so it is entirely correct to find other ways to maintain shareholders' profits.

The theoretical and empirical literature in the field of business organisation expertise has shown concern about the possible influence of corporate social responsibility (CSR) practices on companies' net income, profitability or competitiveness. The conclusions of these studies have not been unanimous, as they reveal various possible results: (1) There is a negative relationship between CSR and financial performance, (2) there is a positive relationship between CSR and financial performance and (3) there is a neutral relationship between CSR and financial performance.

\subsection{Negative relationship between CSR activities and financial performance}

The studies concluding that there is a negative relationship between financial performance and CSR are mainly based on how expenses incurred by responsible behaviour are greater than the economic profits generated by those behaviours. Along these lines, Friedman (1962) argues that a company that maximises its profits by respecting the law and ethics of a market economy fulfils its moral and social responsibilities and has no reason to meet any other kind of demand. This author notes that to accept that companies should be driven to be socially responsible and not merely focused on their shareholders' profits is the equivalent of attacking the basis of our free society.

Several authors remark on the possible agency problems between executives and the ownership of companies. Along these lines, Friedman (2007) and Brammer and Millington (2008) say that CSR can encourage certain executives' behaviours that run against financial performance and are only driven by their private interests. Wright and Ferris (1997) come to the same conclusion.
Cordeiro and Sarkis (1997) find a significant and negative relationship between environmental proactivity and performance expectations for the profit per share for 5 years, in a sample of 523 U.S. companies. Vance (1975) note a negative relationship between CSR practices and companies' profits, while Walley and Whitehead (1994) and Korten (2001) reach a similar conclusion.

\subsection{Positive relationship between CSR activities and financial performance}

All the studies representing a positive causal relationship between CSR and ROE (e.g. Freeman, 2010) defend that coinciding goals between stakeholders and companies strengthen financial performance. In this sense, Bragdon and Marlin (1972); Preston and O'bannon (1997); Orlitzky, Schmidt and Rynes (2003) and Heinze (1976) state similar conclusions.

Porter and Kramer (2006) show this positive relationship is a result of the competitive advantage that CSR generates for companies. Judge and Douglas (1998) found that the level of integration of environmental management issues in strategic planning is positively associated with financial and environmental performance. These results suggest that being concerned about environmental issues can produce competitive advantages.

When considering the question of why markets appreciate CSR activities, several answers can be found: (1) immediate cost saving, (2) improving companies' reputations and (3) deterrence of future actions from regulatory bodies that could result in high costs for companies (Bird, Hall, Momentè \& Reggiani, 2007; Kang, Lee \& Huh, 2010).

Using a resources-based approach, Hart (1995) suggests a competitive advantage theory based on the relationship between companies and the natural environment. Aragon-Correa and Sharma (2003) also come to these conclusions. In addition, Russo and Fouts (1997) analysed 243 Finnish companies, based on a business resources approach. Their results show that 'it is worth it to be green' and that this relationship strengthens with industry growth.

Klassen and McLaughlin (1996) examined businesses whose environmental performance had received awards, on the one hand, and, on the other, companies with a deficient environmental management. The first group of businesses showed immediate higher growth in their market valuation. 
Relative to CSR, Cormier, Magnan and Morard (1993) suggest that spreading audited, non-financial social information through annual reports is beneficial to financial performance. Sturdivant and Ginter (1977) demonstrate not only a relationship between management values and companies' social accountability but also, in general, that strongly socially sensitive businesses show better financial performance than less sensitive ones.

Nicolau (2008) shows that social activities by tourist businesses offer benefits to their society, both directly (inherent to these kinds of activities' purpose) and indirectly (through the businesses' commercial performance). The fact that a company involves itself in tasks apart from its usual business has a positive influence on its financial performance. Waddock and Graves (1997) come to similar conclusions.

Youndt, Snell, Dean and Lepak (1996) examined the performance of human resources in production settings. They conclude that introducing human capital into production quality strategies makes financial performance improve.

In the same way, Pava and Krausz (1996) investigated whether share investors are exclusively interested in earning the highest possible economic benefits for a certain risk quantity. They demonstrate that more and more investors apply social responsibility standards to choose where to invest their funds.

Graves and Waddock (1994) begin with the assumption that institutions invest largely in businesses with good social performance. Their study shows a significant and positive relationship between financial performance and the number of institutions that are shareholders of each company. García-Rodríguez and Armas-Cruz (2007) carried out an empirical study focused on the Spanish hotel sector, drawing conclusions that point to a strong and positive relationship between CSR and profitability.

\subsection{Neutral relationship between CSR activities and financial performance}

Abbott and Monsen (1979) studied the contents of the Fortune 500 companies' annual reports. These show a neutral effect of the companies' social performance on corporate financial performance.

In a similar vein, Alexander and Buchholz (1978) examined the relationship between social responsibility and stock market performance for companies from the USA. They find a significant relationship between low yields - adjusted for risk and levels of social responsibility.

Aupperle, Carroll and Hatfield (1985); Williams, Medhurst and Drew (1993); Teoh, Welch and Wazzan (1999) and Thornton, Kagan and Gunningham (2003) also find no relationship between social responsibility and profitability. Therefore, we deduce that there is no consensus about the causal link between CSR and ROE.

Inoue and Lee (2011) explained such contradictory results by noting three key methodology issues that have not been resolved: (1) the use of multi-industry samples, (2) cross cutting observations and (3) the aggregation of different dimensions. CSR intensity depends on to which specific sector companies belong. Godfrey and Hatch (2007) and Griffin and Mahon (1997) confirm this finding.

Studies of tourist businesses use different dimensions, depending on which research paper we analysed. In this paper, we examine whether CSR practises are communicated on hotel businesses' websites. If the answer is 'yes', we assume that CSR is understood as a tool for a better management.

\section{Corporate social responsability and the hotel industry}

There is no consensus on a definition of CSR. The most accepted statement comes from the Green Book of the European Commission (2001), which declares:

An increasing number of European companies are promoting their corporate social responsibility strategies as a response to a variety of social, environmental and economic pressures. They aim to send a signal to the various stakeholders with whom they interact: employees, shareholders, investors, consumers, public authorities and NGOs. In doing so, companies are investing in their future and they expect that the voluntary commitment they adopt will help to increase their profitability.

The same document states that CSR 'is essentially a concept whereby companies decide voluntarily to contribute to a better society and a cleaner environment (...) a concept whereby companies integrate social and environmental concerns in their business operations and in their interaction with their stakeholders on a voluntary basis'. 
We have analysed the importance of companies' corporate social responsibility and how the relationship between CSR and financial performance has been scientifically studied. It is clear that the literature offers contradictory results. This debate is particularly relevant in the hotel sector due to the intense relationship and dependency this industry has on its environmental setting. From the point of view of offer, the tourist sector - particularly the hotel sector - can come into conflict with certain governments and companies' environmental policies.

The hotel sector is extremely sensitive on this issue, as customers may misunderstand some resource saving measures, thinking they are done only to save costs, to the detriment of quality. In this sense, Kirk (1995) stresses any decision focused on reducing resource consumption has to be communicated to customers (e.g. selective towel laundering or changing the bed linen on alternate days). This author also refers to the high impact tourism can have. However, we should point out that the author neglects to consider how these customers do not dispose of any waste in their own homes, while staying at their hotels.

Butler (1980) studied the implications of the possible decline of tourist destinations due to environmental damage caused by disorganised tourist activity. It is therefore essential to manage environmental resources efficiently when developing competitiveness strategies in tourist destinations and businesses. Hotel activities require more means from the environment and produce waste and emissions in return (Kirk, 1995).

In terms of demand, the importance of CSR in tourism is dramatically rising (Kang et al., 2010). The travellers themselves encourage the tourist sector to adopt responsible attitudes so that their demands can be met (Bremner, 2009). Moreover, an increasing number of people consider the environmental performance of a hotel when booking a room (Gustin \& Weaver, 1996).

At the same time, tourism is deeply sensitive to the violation of labour rights. Substandard conditions for workers and uncontrolled or seasonal subcontracts are only some of the issues linked to these risks.

Hotel business planning should take into account protecting tourists against dishonest commercial practices that can appear in destinations, as well as protect local citizens from the possible negative impacts produced by the arrival of large numbers of visitors. Casanueva, García del Junco and Caro (2001) note that the impact of tourism on the environment must be considered, while the social aspects of how tourist activities interact with locals must not be forgotten either.

\section{Research methodology}

\subsection{Sample and procedure}

The sample studied consisted of the hotels in Malaga, Spain, with an operating revenue higher than one million euros: in total 83 hotels.

Data refer to 2012 and come from the SABI database (the Iberian Balance Sheet Analysis System). SABI contains accounting and financial information on Spanish and Portuguese companies.

In this study, the dependent variable is return on equity (ROE). Jarillo (1992) states that financial performance is extremely important for businesses and is a good indicator of their capacity to pay shareholders.

The economic-financial variables used in this study were: age, operating revenue, number of employees, economic profitability, financial profitability, overall liquidity, debt collection period phase, credit period and employee costs/operating revenue $(\%)$. The main variable under study was employee costs/operating revenue (\%).

On the other hand, to calculate CSR, every hotel's website was analysed to discover whether it contained any communication about CSR practices. A dummy variable was constructed: The website information took the value of 1 if it really communicated CSR practices; otherwise, it took 0. Finally, the analysis was made using ROE as the dependent variable and CSR and employee costs/operating revenue (\%) as the independent variables.

At the same time, we wanted to know whether the obtained results were different in the family firms compared to non family firms. To this end, we created a dummy variable that took on the value of 1 if there was a family firm and of 0 if there was a non family firm. However, the biggest difficulty was to find out which of the hotels were family firms and which of them were not. To that effect, we used the mechanism described by Rojo, Diéguez and López (2011). 


\subsection{Findings and discussion}

Analysis of the variables was carried out using the Statistical Package for Social Sciences version 15.0 (SPSS 15.0) for Windows. A descriptive analysis of the sample was produced, mainly in the form of frequency tables, descriptive statistics and crosstabs. To analyse by crosstabs, the variable ROE was studied by intervals, as was the variable of operating revenue.

Table 1. Crosstab: ROE by CSR

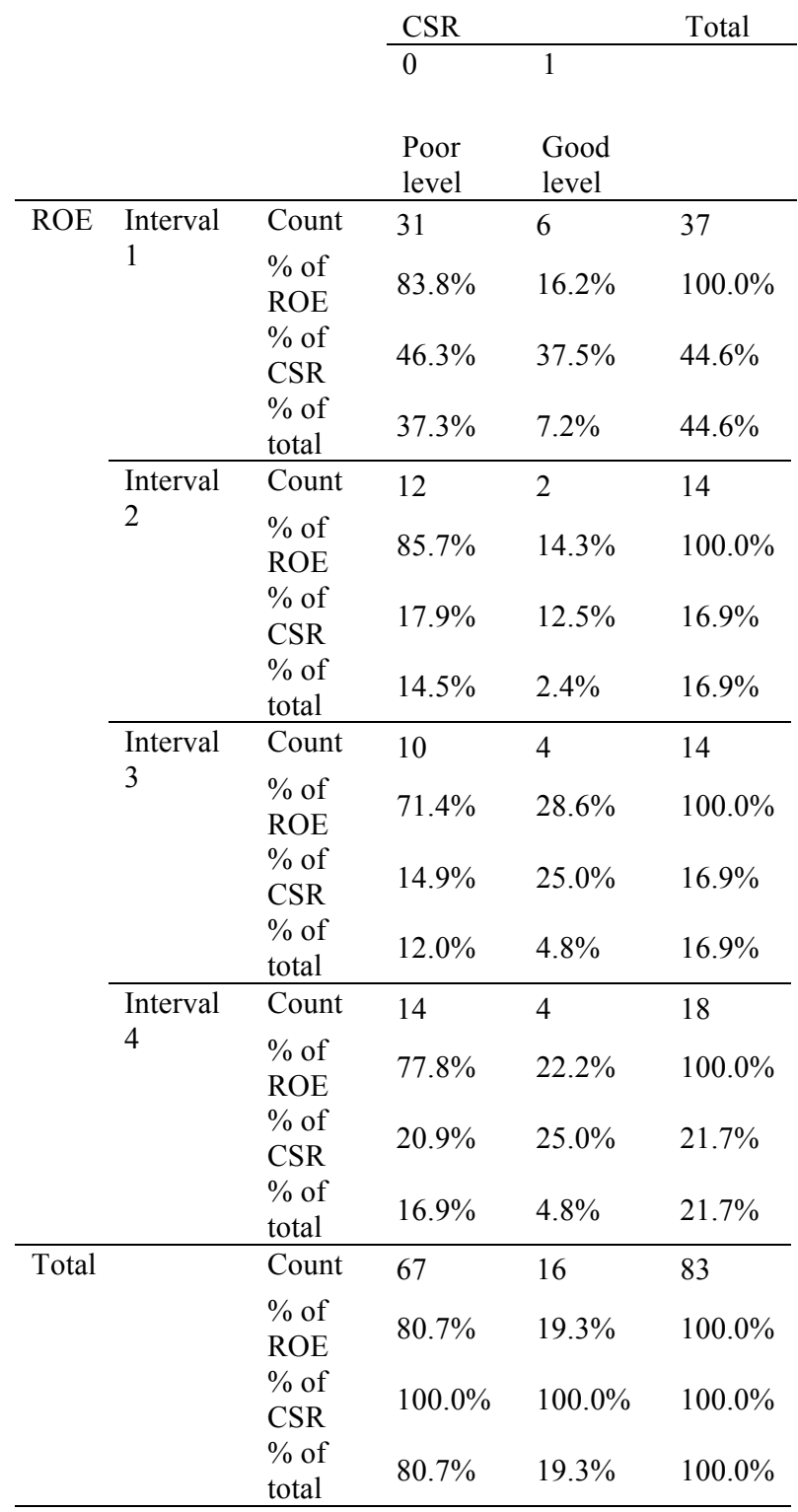

Overall, $19.3 \%$ of the hotels communicate responsible performance in line with CSR on their websites. It is particularly remarkable that hotels with higher financial performance show more reliable attitudes towards CSR. In addition, bigger hotels - understood as having higher operating
Table 2. Crosstab: Operating revenue by CSR

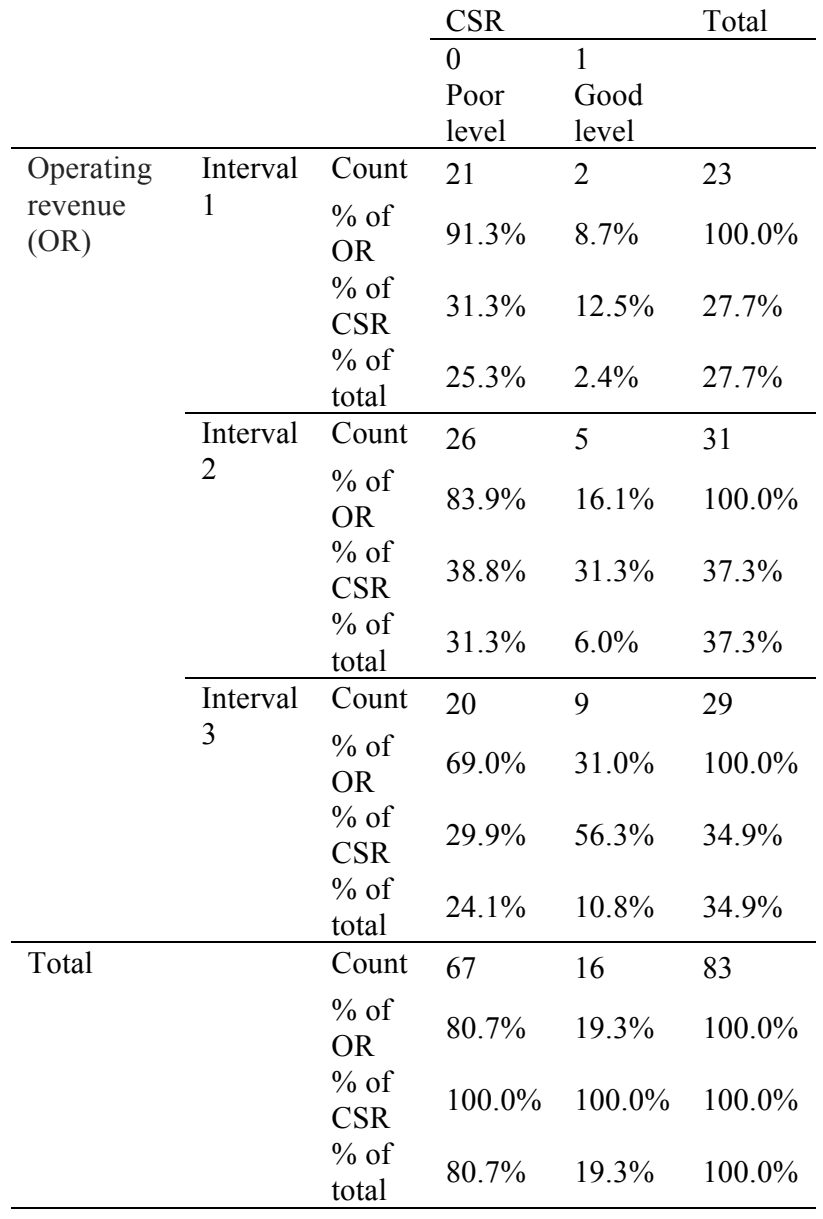

revenues - notably are mainly those that communicate about their CSR activities.

The descriptive analysis shows that CSR and ROE are positively linked, as are CSR and operating revenue. A further step was needed to find out whether this relationship is clearly significant in econometric terms (i.e. whether a higher ROE in hotels is due to their responsible performance, among other things, and that the hotels present a higher operating revenue because they are more responsible).

The variable called "family firm" was introduced. The family firms' performance regarding the CSR was compared to be analysed by crosstabs. The results are shown on Table 3 .

The analysis by crosstabs shows that $26.1 \%$ of family firms have a good level of communication for their CSR practices. However, if we focus on non family firms, only $17.7 \%$ of them communicate CSR practices. We deduced from these data that, for this sample, family firms are more interested in CSR. 
Table 3. Crosstab: Family firm by CSR

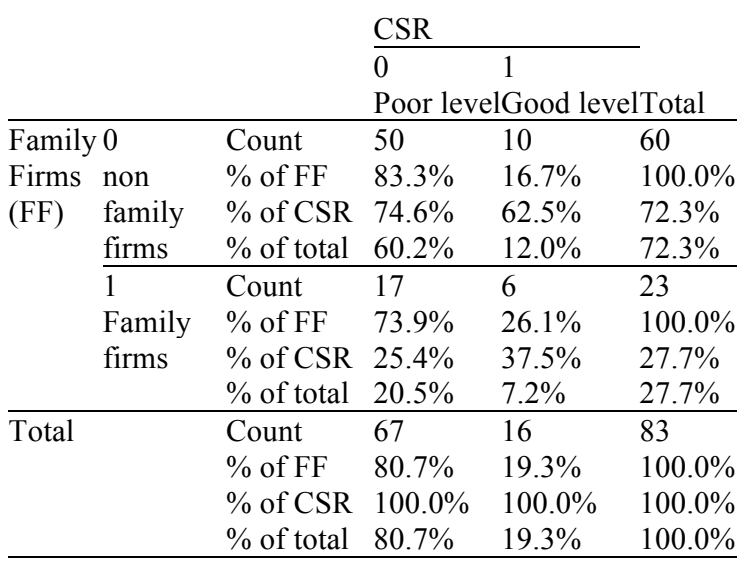

For the econometric analysis, a multiple linear regression model was used to predict the value of the dependent variable. In addition, the coefficients of the independent variables that best predict the value of the dependent variable were estimated.

The F-ratio in the ANOVA table (see Table 4) tests whether the overall regression model is a good fit for the data. The table shows that the independent variables predict, at a statistically significant level, the dependent variable, $\mathrm{F}(2.80)=3.341 \mathrm{p}<0.05$ (i.e. the regression model is a good fit of the data).
Unstandardised coefficients indicate how much the dependent variable varies with an independent variable, when all other independent variables are held constant. The unstandardised coefficient, B1, for employee costs/operating revenue (\%) is equal to -2.351 (see Table 5). This means that for each $1 \%$ increase in employee costs/operating revenue (\%), there is a decrease in ROE of $2.351 \%$.

Each of the independent variables was tested for statistical significance. This reveals whether the unstandardised (or standardised) coefficients are equal to 0 (zero) in the population. If $p<0.10$, it can be concluded that the coefficients are different to 0 (zero) to a statistically significant degree. The tvalue and corresponding p-value are located in the " $t$ " and "Sig." columns, respectively, as shown in Table 4

If $\mathrm{p}<0.10$, it can be concluded that the employee costs/operating revenue (\%) coefficient is different to 0 (zero) at a statistically significant level. ROE significantly depends on the employee costs/operating revenue (\%) variable. However, CSR does not influence the variable ROE.

Table 4. ANOVA (b)

\begin{tabular}{lllllll} 
Model & & Sum of squares & df & Mean square & F & Sig. \\
\hline 1 & Regression & $100,433.113$ & 2 & $50,216.556$ & 3.341 & 0.040 (a) \\
& Residual & $1,202,551.473$ & 80 & $15,031.893$ & & \\
& Total & $1,302,984.585$ & 82 & & & \\
\hline
\end{tabular}

(a) Predictors: (Constant), CSR, employee costs/operating revenue (\%).

(b) Dependent variable: ROE

Source: Authors

Table 5. Model 1. Coefficients ${ }^{(\mathrm{a})}$

\begin{tabular}{|c|c|c|c|c|c|c|}
\hline \multirow{3}{*}{$\begin{array}{l}\text { Model } \\
1\end{array}$} & \multirow[b]{3}{*}{ (Constant) } & \multicolumn{2}{|c|}{$\begin{array}{l}\text { Unstandardised } \\
\text { coefficients }\end{array}$} & \multicolumn{2}{|c|}{$\begin{array}{l}\text { Standardised } \\
\text { coefficients }\end{array}$} & \multirow[b]{2}{*}{ Sig. } \\
\hline & & $\mathrm{B}$ & Std. Error & Beta & $\mathrm{t}$ & \\
\hline & & 110.181 & 42.422 & & 2.597 & 0.011 \\
\hline & $\begin{array}{l}\text { Employee } \\
\text { costs/ } \\
\text { operating } \\
\text { revenue (\%) }\end{array}$ & -2.351 & 0.910 & -0.285 & -2.582 & 0.012 \\
\hline & CSR & -17.353 & 35.082 & -0.055 & -0.495 & 0.622 \\
\hline
\end{tabular}

${ }^{(a)}$ Dependent variable: ROE

Source: Authors 
Table 6. Model 2. Coefficients ${ }^{(a)}$

$\begin{array}{ll}\text { Unstandardised } & \begin{array}{l}\text { Standardised } \\ \text { coefficients }\end{array} \\ \text { coefficients }\end{array}$

\begin{tabular}{|c|c|c|c|c|c|c|}
\hline \multirow[t]{5}{*}{ Model 2} & \multirow[b]{2}{*}{ (Constant) } & B & Std. Error & Beta & $\mathrm{t}$ & Sig. \\
\hline & & 112.057 & 42.656 & & 2.597 & 0.010 \\
\hline & $\begin{array}{l}\text { Employee } \\
\text { costs/ } \\
\text { operating } \\
\text { revenue (\%) }\end{array}$ & -2.274 & 0.921 & -0.276 & -2.582 & 0.016 \\
\hline & CSR & -14.139 & 35.518 & -0.045 & -0.495 & 0.692 \\
\hline & Family Firm & -20.747 & 30.581 & -0.074 & -0.678 & 0.499 \\
\hline
\end{tabular}

${ }^{(a)}$ Dependent variable: ROE

Source: Authors

The employee costs/operation revenue (\%) ratio is the variable that most affects all the data analysed. The ratio depends on the companies' management. Therefore, we must say that good management is paramount. The monitoring of this ratio is essential for hotels to improve their ROE. CSR does not affect ROE - either negatively or positively; instead, these have a neutral relationship.

A new regression was made, this time by introducing the dummy variable "family firm" as well. We did not find any causal relationship, that is to say, the relation between ROE and family firm was neutral, as it is shown on table 6 .

\section{Conclusions}

Friedman (1962) has said companies that maximise their benefits by respecting the law and the ethics of a market economy fulfil their moral and social responsibilities and have no reason to pay attention to any other requirements. However, over the years, people and businesses have become increasingly aware of environmental and social issues. The CSR concept is spreading among companies that want to become leaders. Corporate awareness implies being economically, socially and environmentally sustainable.

This new trend helps build a better future, without doubt. However, does it produce profit for shareholders?

Investigators have focused on analysing whether having good CSR attitudes increases companies' profitability. Many studies note a positive relationship between those two variables, but there is a lack of unanimity, with papers showing three relationships: positive, negative and neutral. These differences found in the results may arise from the difficulty of properly measuring CSR.
This paper has shown a neutral relationship between the two variables, which means introducing CSR measures stop short of having a negative effect on shareholders' profits. Therefore, based on the results of this study, we encourage the hotel sector to introduce CSR practices into its strategy, as CSR produces new competitive advantages that have neutral effects on financial performance. What begins as a competitive advantage - no matter the ROE - in the near future will surely become a crucial requirement to compete effectively. The conclusions were not different once we distinguished between family or non family firms.

At the same time, this study finds that CSR communication on websites is an effective practice in terms of CSR, without taking into account those companies that have good CSR practices but do not communicate them on their websites. Communicating good practices, explaining areas of improvement and achievements are inseparable issues in the application of CSR policies in every organisation.

Calculating CSR measures using Global Reporting Initiative (GRI) principles and comparing these with this study's results will be a further line of research. GRI suggests several indicators as a basis for CSR communication in organisations. Adopting this list as a starting point from which to find organisations' good practices and then determining their ROE can be another project. Further research can use the same analysis in other sectors besides hotels. This would help check whether the relationship between CSR and ROE stays neutral.

One of the most common excuses business owners and executives use to justify having no CSR policies is that they cannot afford to spend money on these activities, as they will affect their companies' profitability. This study has demonstrated that CSR 
has a neutral relationship with ROE, and, consequently, other benefits (e.g. reputation and competitiveness) will arise from applying those practices, without weakening ROE.

\section{References}

Abbott, W. F., \& Monsen, R. J. (1979). On the measurement of corporate social responsibility: selfreported disclosures as a method of measuring corporate social involvement. Academy of Management Journal, 22(3), 501-515.

Alexander, G. J., \& Buchholz, R. A. (1978). Corporate social responsibility and stock market performance. Academy of Management journal, 21(3), 479-486.

Aragon-Correa, J. A., \& Sharma, S. (2003). A contingent resource-based view of proactive corporate environmental strategy. Academy of Management Review, 28(1), 71-88

Aupperle, K. E., Carroll, A. B., \& Hatfield, J. D. (1985). An empirical examination of the relationship between corporate social responsibility and profitability. Academy of Management Journal, 28(2), 446-463.

Bird, R., Hall, A. D., Momentè, F., \&Reggiani, F. (2007). What corporate social responsibility activities are valued by themarket? Journal of Business Ethics, 76(2), $189-206$

Bragdon, J. H., \& Marlin, J. (1972). Is pollution profitable. Risk Management, 19(4), 9-18.

Brammer, S., \& Millington, A. (2008). Does it pay to be different? An analysis of the relationship between corporate social and financial performance. Strategic Management Journal, 29(12), 1325-1343.

Bremner, C. (2009). Sustainable tourism moves slowly in the right direction. Retrieved from, 2009.

Butler, R. W. (1980). The concept of a tourist area cycle of evolution: implications for management of resources. The Canadian Geographer/Le Géographe Canadien, 24(1), 5-12.

Casanueva, C., García del Junco, J., \& Caro, F. J. (2000). Organización y gestión de empresas turísticas.

Cordeiro, J. J., \& Sarkis, J. (1997). Environmental proactivism and firm performance: evidence from security analyst earnings forecasts. Business Strategy and the Environment, 6(2), 104-114.

Cormier, D., Magnan, M., \& Morard, B. (1993). The impact of corporate pollution on market valuation: some empirical evidence. Ecological Economics, 8(2), 135155 .

Drogendijk, R., \& Slangen, A. (2006). Hofstede, Schwartz, or managerial perceptions? The effects of different cultural distance measures on establishment mode choices by multinational enterprises. International Business Review, 15(4), 361-380.

European Commission (2001). Green Paper: promoting a European framework for corporate social responsibility, European Commission.

Freeman, R. E. (2010). Strategic management: A stakeholder approach. Cambridge University Press.

Friedman, M. (1962) Capitalism and freedom. University of Chicago Press: Chicago.

Friedman, M. (2007). The social responsibility of business is to increase its profits (pp. 173-178). Springer Berlin Heidelberg.

García-Rodríguez, F. J. \& Armas-Cruz, Y. (2007). Relation between social-environmental responsibility and performance in hotel firms. International Journal of Hospitality Management, 26(4), 824-839.

Gémar, G. \& Jiménez, J.A. (2013). Retos estratégicos de la industria hotelera española del siglo xxi: horizonte 2020 en países emergentes. Tourism \& Management Studies, 9 (2), 13-20.

Gémar, G. (2014). Influence of cultural distance on the internationalisation of Spanish hotel companies. Tourism \& Management Studies, 10(1), 31-36.

Graves, S. B., \& Waddock, S. A. (1994). Institutional owners and corporate social performance. Academy of Management Journal, 37(4), 1034-1046.

Godfrey, P. C., \& Hatch, N. W. (2007). Researching corporate social responsibility: an agenda for the $21 \mathrm{st}$ century. Journal of Business Ethics, 70(1), 87-98.

Griffin, J. J., \& Mahon, J. F. (1997). The corporate social performance and corporate financial performance debate twenty-five years of incomparable research. Business \& Society, 36(1), 5-31.

Gustin, M. E., \& Weaver, P. A. (1996). Are hotels prepared for the environmental consumer? Journal of Hospitality \& Tourism Research, 20(2), 1-14.

Hart, S. L. (1995). A natural-resource-based view of the firm. Academy of Management Review, 20(4), 9861014 .

Heinze, D. C. (1976). Financial correlates of a social involvement measure. Akron Business and Economic Review, 7(1), 48-51.

Inoue, Y., \& Lee, S. (2011). Effects of different dimensions of corporate social responsibility on corporate financial performance in tourism-related industries. Tourism Management, 32(4), 790-804.

Jarillo, J. C. (1990). Estrategia internacional. Madrid: McGraw-Hill.

Jarillo, J. C. (1992). Dirección estratégica. McGrawHill.

Judge, W. Q., \& Douglas, T. J. (1998). Performance implications of incorporating natural environmental issues 
into the strategic planning process: an empirical assessment. Journal of Management Studies, 35(2), 241262.

Kang, K. H., Lee, S., \& Huh, C. (2010).Impacts of positive and negative corporate social responsibility activities on company performance in the hospitality industry. International Journal of Hospitality Management, 29(1), 72-82.

Kim, Y., \&Gray, S. J. (2009). An assessment of alternative empirical measures of cultural distance: Evidence from the Republic of Korea. Asia Pacific Journal of Management, 26(1), 55-74.

Kirk, D. (1995). Environmental management in hotels. International Journal of Contemporary Hospitality Management, 7(6), 3-8.

Klassen, R. D., \& McLaughlin, C. P. (1996). The impact of environmental management on firm performance. Management Science, 42(8), 1199-1214.

Kogut, B., \& Singh, H. (1988). The effect of national culture on the choice of entry mode. Journal of International Business Studies, 19(3), 411-432.

Korten, D. C. (2001). When corporations rule the world. Berrett-Koehler Publishers.

López-Duarte, C., \& Vidal-Suárez, M. M. (2010). External uncertainty and entry mode choice: Cultural distance, political risk and language diversity. International Business Review, 19(6), 575-588.

Morschett, D., Schramm-Klein, H., \&Swoboda, B. (2008). Entry modes for manufacturers' international after-sales service: analysis of transaction-specific, firmspecific and country-specific determinants. Management International Review, 48(5), 525-550.

Nicolau, J. L. (2008). Corporate Social Responsibility: Worth-Creating activities. Annals of Tourism Research, 35(4), 990-1006.

Orlitzky, M., Schmidt, F. L., \& Rynes, S. L. (2003). Corporate social and financial performance: A metaanalysis. Organisation Studies, 24(3), 403-441.

Pava, M. L., \& Krausz, J. (1996). The association between corporate social-responsibility and financial performance: The paradox of social cost. Journal of Business Ethics, 15(3), 321-357.

Plá, J. \& León, F. (2004). Dirección de empresas internacionales. Madrid: Pearson Prentice Hall.

Porter, M. E., \& Kramer, M. R. (2006). The link between competitive advantage and corporate social responsibility. Harvard Business Review, 84(12), 78-92.

Preston, L. E., \& O'bannon, D. P. (1997). The corporate social-financial performance relationship. Business and Society, 36(4), 419-429.

Rojo, A., Diéguez, J., \& López, P. (2011). Importancia del concepto de Empresa Familiar en investigación: utilización de la base de datos SABI para su clasificación. Revista de Empresa Familiar, 1(1), 53-67.

Russo, M. V., \& Fouts, P. A. (1997). A resourcebased perspective on corporate environmental performance and profitability. Academy of Management Journal, 40(3), 534-559.

Sturdivant, F. D., \& Ginter, J. L. (1977). Corporate Social Responsiveness: Management Attitudes and Economic Performance. California Management Review, 19(3).

Teoh, S. H., Welch, I., \& Wazzan, C. P. (1999). The Effect of Socially Activist Investment Policies on the Financial Markets: Evidence from the South African Boycott. The Journal of Business, 72(1), 35-89.

Thornton, D., Kagan, R. A., \& Gunningham, N. (2003). Sources of corporate environmental performance. California Management Review, 46(1), 127-141.

Vance, S. C. (1975). Are socially responsible corporations good investment risks. Management Review, 64(8), 19-24.

Waddock, S. A., \& Graves, S. B. (1997). The corporate social performance. Strategic Management Journal, 8(4), 303-319.

Walley, N., \& Whitehead, B. (1994). It's not easy being green. The Earthscan reader in business and the environment, 36-44.

Williams, H. E., Medhurst, J., \& Drew, K. (1993). Corporate strategies for a sustainable future. Environmental Strategies for Industry, 117-146.

Wright, P., \& Ferris, S. P. (1997). Agency conflict and corporate strategy: The effect of divestment on corporate value. Strategic Management Journal, 18(1), 77-83.

Youndt, M. A., Snell, S. A., Dean, J. W., \& Lepak, D. P. (1996). Human resource management, manufacturing strategy, and firm performance. Academy of Management Journal, 39(4), 836-866. 